\title{
Attempting to Keep a Low Profile: The Revolutions in Somalia and Ethiopia
}

In the mid-1970s, the military regimes that took power in Somalia in 1969 and in Ethiopia in 1974 sought to strengthen their links to the Soviet Union. Subsequently, the Horn of Africa turned into a second trouble spot for Switzerland's foreign policy on the African continent, after Southern Africa. The 1969 military coup in Somalia had domestic causes. From 1967 onwards, Prime Minister Mohammad Egal had taken a more conciliatory, less aggressive approach to the nationalist goal of adding neighbouring territories inhabited by ethnic Somalis to the Somali state. His attempt to resolve the issue by diplomatic means caused public dissatisfaction and left the army without a raison d'être. During the March 1969 elections, violent clashes erupted between different political parties and there were widespread accusations of corruption. This further undermined confidence in the government. On 15 October 1969, while Prime Minister Egal was on a visit to the US, President Ali Shermarke was shot by one of his police guards. Six days later, the army took power in a bloodless coup. The Supreme Revolutionary Council under General Mohammad Siad Barre arrested government officials, including the returned Egal, suspended the constitution, abolished the Supreme Court, closed parliament, and renamed the state the Somali Democratic Republic. The new regime promised to fight corruption, continue the struggle for the unification of all Somali people, and work for the improvement of economic and social conditions. ${ }^{1}$ In the months after the coup, Soviet military and economic delegations visited Mogadishu. ${ }^{2}$ Nevertheless, Soviet involvement in Somalia increased moderately at first. It was only after Egypt's President Anwar Sadat expelled all Soviet military and technical advisors in July 1972 that Somalia and its ports gained great strate-

1 Laitin, Samatar, Somalia, pp. 76-79; Lewis, A Modern History of the Somali, pp. 203-207.

2 Therefore, many contemporary Western observers concluded that the Soviet Union was involved in the events of 21 October. The two most detailed historical analyses of the Soviet Union's role in the Horn of Africa nuance this view. Robert Patman argues that the Kremlin did not orchestrate the coup, although it anticipated and probably encouraged it. Based on extensive archival research, Radoslav Yordanov concludes that while the Soviet Committee for State Security (кGв) was informed in advance about the coup, there is no evidence of direct Soviet involvement: Patman, The Soviet Union in the Horn of Africa, pp. 95-97; Yordanov, The Soviet Union and the Horn of Africa, pp. 89-91. 
gic importance for the Kremlin. Consequently, the Soviet presence in Somalia grew markedly, particularly in the military field. Yet, although the two states concluded a friendship treaty in July 1974, Siad Barre was not Moscow's puppet. Introducing socialism in a strongly clan-based Muslim society with a large nomadic population called for pragmatic policies that were not always in line with Soviet prescriptions for socialist development. Siad Barre also guarded his independence in the field of foreign policy, where he adopted a neutralist approach. ${ }^{3}$

In 1974, Ethiopian leaders also started to turn towards the USSR. Early in the year, the dissatisfaction with Ethiopia's feudal regime and the long reign of Haile Selassie that had been growing since 196o erupted. Ethiopian scholars underline the importance of an abortive coup in 196o, instigated by members of the Imperial Bodyguard, which heralded more than a decade of open political protest. In several rural areas, peasants rose up against heavy taxation and exploitation by a landholding elite. In Eritrea, whose autonomy in the UN-decreed federation with Ethiopia had been steadily eroded, liberation movements started to fight for independence in 1961. The Ethiopian student movement also became more outspoken after 1960, and became the dominant force of opposition until the end of the regime. Increasingly radicalised from the mid-196os onwards, Ethiopian students were part of the international student protest movement and had associations in Europe and the US. Student groups challenged the authority of the regime, demanding land reforms and civic liberties, and declaring the right of nationalities to self-determination. ${ }^{4}$ A devastating famine that mainly hit the provinces of Wollo and Tigre in 19731974, costing the lives of an estimated 100,000-200,000 people in 1973, also contributed to the erosion of the regime's legitimacy. Haile Selassie's government was criticised for its lack of action when failing rains in 1972 brought drought, the official cover-up of the situation, and the continuation of grain exports during the famine. ${ }^{5}$

The Ethiopian Revolution began in mid-January 1974 with the mutiny of an army brigade in southern Ethiopia over salaries and social issues, which ended only when the Emperor sent a letter promising to look into the demands. The incident created unrest within the army, where coordinating committees were set up to manage the armed forces' claims. In mid-February, a civilian uprising

3 See Yordanov, The Soviet Union and the Horn of Africa, pp. 85-102.

4 Bahru Zewde, A History of Modern Ethiopia, pp. 209-226; Gebru Tareke, The Ethiopian Revolution, pp. 11-14, 24-34.

5 Edmond J. Keller, Revolutionary Ethiopia: From Empire to People's Republic, Bloomington: Indiana University Press, 1991, pp. 166-167. 
started in Addis Ababa and soon spread to neighbouring towns and provincial capitals. Taxi drivers, teachers, and students went on strike and organised demonstrations against educational reform programmes and rising petrol prices caused by the international oil crisis, and were quickly joined by the city's unemployed. The government's reaction was contradictory: on the one hand, security forces were authorised to use force against demonstrators and looters; on the other hand, Haile Selassie publicly promised that many of their demands would be met. A few days later, the Ethiopian Prime Minister, who had occupied his post since 1961, was forced to resign. The appointment of a new cabinet did little to calm public protests, however, and did not prevent the Confederation of Ethiopian Labour Unions from joining the fight and organising a general strike that lasted for four days and ended with all demands being met. ${ }^{6}$ Nevertheless, discontent within the population and the army continued.

In late June 1974, the Coordinating Committee of the Armed Forces, Police, and Territorial Army was established, later called variously the Armed Forces Committee, the Provisional Military Administrative Council (PMAC) or the Derg (committee in Amharic). Over the following months, the committee gradually took over the functions of the government. Its policies were summarised in a policy statement called 'Ethiopia First' and published on 10 July. They included loyalty to the Emperor, constitutional reform and the prosecution of corrupt officials, and more rights and improved living conditions for the people. ${ }^{7}$ On 12 September 1974, Haile Selassie was arrested and detained, and the PMAC assumed power. Its chairman, Lieutenant General Aman Mikael Andom, acted as the new head of state. The Derg suspended the constitution, dissolved parliament, and prohibited strikes and demonstrations, thereby alienating many of the groups that had been instrumental to the popular uprisings of the first half of $1974 .{ }^{8}$ Over the following months and years, the PMAC would enact a series of radical reforms, strengthen its links to the USSR, and turn away from the US - which had supported the old regime. Haile Selassie would be killed sometime in 1975 .

The radical regime changes in the Horn of Africa drew the attention of the Swiss government to an area of the world where Switzerland's political and economic interests were few, and in the case of Somalia practically non-existent. In neighbouring Ethiopia, Switzerland's commercial relations were limited due to the African country's poverty and lack of agricultural and industrial development. Bern had cordial but low-key relations with the ruling Emperor

6 Andargachew Tiruneh, The Ethiopian Revolution, pp. 37-44.

7 Ibid., pp. 61-71.

8 Bahru Zewde, A History of Modern Ethiopia, p. 236. 
Haile Selassie and increased its development cooperation in this state in the early 1970s. The presence of the superpowers in the Horn of Africa ensured that events in this region were closely scrutinized in Bern. The progressively Marxist turn of Mohammad Siad Barre's regime preoccupied the anti-Communist Swiss government. The increasing radicalisation of Ethiopia's new elites, together with FRELIMO coming to power in Mozambique in June 1975 and the MPLA's victory in the Angolan War in early 1976, sparked fears of rapidly increasing Soviet influence on the African continent. At the same time, Ethiopia hosted the headquarters of the OAU and numerous international and regional organisations, and was therefore frequently referred to as 'Africa's capital'. The strong diplomatic presence in Addis Ababa as well as Haile Selassie's renown as one of Africa's most distinguished elderly statesmen ensured that the events in Ethiopia were observed with particular interest, both in Switzerland and around the world. The OAU had, in the early 1970s, increased its pressure on the Swiss government to change its one-sided policy on Southern Africa, and discussed the introduction of sanctions against foreign firms dealing with the white minority regimes. The new Ethiopian regime's appeals, starting in September 1974, for the restitution of public funds that the deposed Emperor had allegedly deposited in Swiss bank accounts were therefore particularly damaging to Switzerland's image in sub-Saharan Africa. Once again, it was Switzerland's economic —in this case financial—role in the Horn of Africa that sparked controversy and induced its political leaders to try to keep a low profile.

\section{“Do We Actually Have Diplomatic Relations?" Swiss-Somali Links after the ${ }_{1969}$ Coup d'État}

In August 1975, the Somali ambassador to Tanzania asked his Swiss counterpart in Dar es Salaam whether the two states had diplomatic relations. ${ }^{9}$ His question was symptomatic of the mutual indifference that marked SwissSomali relations. There was little that bound the two states together. Economic exchanges were close to zero and aid extremely limited, even by Swiss standards. Only the Somali Democratic Republic's tightening links to the USSR after the 1969 coup d'état sporadically attracted Bern's attention.

The October 1969 military coup in Somalia did not provoke a strong reaction in Switzerland. André Parodi, Swiss ambassador to Egypt who was also

9 Cited in Claude Huguenin, DPA, memorandum, "Visite de l'Ambassadeur Jaccaud auprès du Chef de la Division II, le 13 août 1975”, 25.08.1975, p. 3, SFA E20o1E-oı\#1987/78\#4651*. 
accredited to Somalia, noted a few weeks after the coup that the new regime turned increasingly Marxist and multiplied its contacts with the Communist bloc. From this, he concluded that no intensification in economic exchange between Switzerland and Somalia was to be expected. ${ }^{10}$ In mid-December, Parodi forwarded a confidential report from the West German Embassy in Mogadishu, which was studied with great attention by several FPD officials. According to the heavy underlining, interest focused mainly on the new regime's ideological background and its contacts with the Soviet Union. ${ }^{11}$ Bilateral relations were scarcely affected in the immediate aftermath of the coup. The sTC's planning for the grant of scholarships to twelve Somali teachers to study in the Italian-speaking part of Switzerland, begun in 1969, continued in spite of the regime change and was abandoned in July 1970 by mutual consent. ${ }^{12}$ The new regime's nationalisations of banks and power stations in February 1970 did not touch Swiss interests. ${ }^{13}$

In the early 1970s, issues linked to Switzerland's diplomatic representation in Somalia occasionally drew the FPD's attention to this state. In late June 1970, the Swiss honorary consul, Robert Camenzind, was forced to leave the country within 24 hours, ostensibly for subversive activities. Ambassador Parodi speculated, however, that Camenzind's links to the old regime as well as his frequent travels, which included trips to Somalia's enemy-Ethiopia, had raised the Somali government's suspicions. Both Parodi and the DPA concluded that the consul's expulsion should not be considered an unfriendly act towards Switzerland and that bilateral relations should be upheld. ${ }^{14}$ The expulsion of another Swiss citizen who worked for the UNDP a few months later was explained by Parodi as due to the intrigues of the Soviet head of the organisation in Somalia: "This episode is mainly remarkable because it shows, once again, how the Communist states take every opportunity to increase their influence in devel-

10 Letter from André Parodi, Swiss ambassador in Egypt, to the Protocol Service of the FPD, "Relations avec le Soudan et la Somalie", confidential, o2.12.1969, p. 2, SFA E20o1E-o1\#1991/ 17_Bd.1096, B.15.21.

11 Letter from André Parodi to Pierre Micheli, Secretary-General of the FPD, "Situation en Somalie après le putsch militaire", 12.12.1969, SFA E20o1E\#1980/83\#4051* and the attached report by the German embassy in Somalia, "Lage in Somalia", no author, no date. It was mainly due to a change in the Somali curriculum which rendered Italian-speaking teachers superfluous: letter from André Parodi to the STC, "Instruction publique - Cours pour enseignants somaliens", pp. 1-2, 06.07.1970, SFA E2005A\#1983/18\#794*.

See, for example, the letter from André Parodi to the sтc, "Technische Zusammenarbeit mit Somaliland", 19.10.1970, SFA E2005A\#1983/18\#794*.

14 Letter from André Parodi to the DPA, confidential, 08.07.1970, SFA E2O04B\#199o/219\#615*; note from Michael Gelzer, deputy chief of the DPA, to the AD, "Beziehungen mit Somalia und Konsularagentur in Mogadiscio", 20.07.1970, ibid. 
oping states. They do not hesitate to use international organisations for their own purposes and at the expense of Western member states."15 A year later, Parodi warned the Swiss export promotion agency not to be too hopeful with regard to economic opportunities for Swiss pharmaceutical firms in Somalia because of the regime's "socialist tendencies" ${ }^{16}$ After Parodi left his post in August 1971, the Swiss government transferred responsibility for diplomatic relations with Somalia from the Swiss embassy in Egypt to that in Tanzania, mainly for organisational reasons. Yet, in the words of the FPD's proposal to the Federal Council in May 1971, the greater geographical proximity of Dar es Salaam and Mogadishu was echoed in ideological affinities, as both governments "share equally progressive political views."17 The comparison of Siad Barre's policies with Julius Nyerere's vision of an African Socialism based on the development of rural villages shows that the Somali regime's ideological outlook was not initially considered unusual for an African state. ${ }^{18}$

In late 1974, in the midst of the Ethiopian Revolution and at a time when the independence of Mozambique and Angola was certain, the Swiss authorities decided to close their consulate in Mogadishu and forego the accreditation of a Swiss ambassador to Somalia. This amounted to an unofficial severance of diplomatic relations between the two states. The decision was triggered by the recommendation of the Somali ambassador in Tanzania that his Swiss counterpart, Lucien A. Mossaz, in October 1974, should skip his farewell visit to Mogadishu because the Somali authorities had no time for him. As this was the second time in one year that Mossaz was discouraged from travelling to Somalia, the FPD decided in December to definitively close the Swiss consular agency in Mogadishu, which had been temporarily shut since Camenzind's expulsion..$^{19}$ Given Somalia's marginal importance for and unfriendly attitude towards Switzerland, the FPD also decided that the accreditation of another

15 Letter from André Parodi to the STC, "PNUD-Delegationen in unterentwickelten Ländern", p. 2, 17.12.1970, SFA E2005A\#1983/18\#794*.

16 Letter from André Parodi to the oSEC, 23.08.1971, p. 2, SFA E2001E-o1\#1982/58\#66o3*

17 Pierre Graber, Federal Councillor and head of the FPD, proposal to the Federal Council, "Modification de la competence juridictionnelle des ambassades du Caire et de Dar es Salaam" (inter alia), 24.05.1971, secret, p. 3, SFA E2004B\#1982/69\#122*. On Nyerere's vision of Socialism, see Vijay Prasad, The Darker Nations. A People's History of the Third World, New York: The New Press, 2007, pp. 191-203.

19 Letter from Lucien A. Mossaz, Swiss ambassador in Tanzania, to Antonino Janner, head of the AD, "Visite d'adieu en Somalie", o8.10.1974, confidential, SFA E2004B\#199o/219\#615* and handwritten comments on this document; letter from Alfred Glesti, AD, to the Swiss embassy in Tanzania, "Agence consulaire à Mogadiscio", o8.01.1975, SFA E2004B\#199o/ $219 \# 615^{*}$. 
Swiss ambassador to this country was not necessary for the time being. ${ }^{20}$ The Swiss government's tacit decision to let matters rest met with little interest and caused no rupture between the two states.

This decision was only criticised once. In late 1976, after the Soviet-allied MPLA had won the Angolan War, Richard Pestalozzi, Swiss ambassador to Kenya and one of the FPD's foremost advocates for a more active policy towards the Third World, urged his superiors to take up diplomatic relations with Somalia again. Pestalozzi argued that, even if the Somali regime's treatment of Camenzind and Mossaz had been unfriendly, the Swiss authorities should be more tolerant of Third World states. He underlined that the lack of a diplomatic representation in Somalia was not only contrary to the principle of universality in foreign relations, but also facilitated Soviet influence in the country. Finally, Pestalozzi insisted that a consulate was also of practical importance, as Switzerland had, through charitable organisations such as the Swiss Red Cross (SRC), repeatedly granted humanitarian aid to the droughtand famine-stricken country. ${ }^{21}$ Bern did not comment on the argument that Switzerland had a share in the Western bloc's responsibility to contain Soviet influence in the Third World. The deputy head of the DPA's African, Asian, Middle Eastern and Latin American Division, Hansjakob Kaufmann, simply replied that the decision not to accredit an ambassador to Somalia was due to budget constraints. ${ }^{22}$

Thus, in late 1976, diplomatic relations between Switzerland and Somalia were de facto suspended. Somalia's limited political and economic importance for Switzerland, its unfriendly attitude towards Swiss representatives to the country, and the troubled state of federal finances certainly explain why the FPD decided to ignore the principle of universality in the case of Somalia. However, the question of the extent to which the ideological orientation of Siad Barre's regime influenced this decision needs to be addressed. The Somali government's links with the Soviet Union were never mentioned in discussions about the state of bilateral relations from late 1974 onwards. To conclude that they did not play a role, or that a socialist Somalia was not considered a danger to overall Swiss interests would be too simple, especially considering the Swiss authorities'

20 Bernard Freymond, FPD, minutes of the 1oth meeting of Commission I (representations) of the 'Florian' working group on 5 December 1974, 09.12.1974, p. 3, SFA E2004B\#1996/399\#12*. Letter from Richard Pestalozzi, Swiss ambassador in Kenya, to the DPA, "Diplomatische Vertretung in Somalia", 11.10.1976, SFA E2004B\#199o/219\#381*; see also letter from Pestalozzi to the DPA and the AD, "Diplomatische Vertretung in Somalia", 20.08.1976, ibid. Letter from Hansjakob Kaufmann, deputy chief of the DPA's African, Asian, Middle Eastern and Latin American Division, to the Swiss embassy in Kenya, "Diplomatische Vertretung in Somalia", 22.11.1976, SFA E2004B\#1990/219\#381*. 
generally anti-Communist position. It seems more probable that, unlike Ambassador Pestalozzi, most FPD leaders did not feel responsible for maintaining relations with Somalia and thereby trying to influence its government's ideological orientation. They appear to have been content to delegate this responsibility to the bigger members of the Western bloc, first and foremost the US.

\section{2 "Eventful Times": Reactions to the 1974 Ethiopian Revolution}

The Ethiopian Revolution was not entirely unexpected to the Swiss authorities, as Haile Selassie's reign had long been disputed. However, the radical turn it would take caught them off guard. The Somali coup d'état five years previously had certainly not prepared them for the profound effects that the revolution would have on Swiss-Ethiopian relations. The military and civilian uprisings that broke out in Ethiopia in early 1974 and led gradually to the deposition of Emperor Haile Selassie and the takeover by a military regime in September of the same year, did not immediately raise concern in Bern. Kept abreast of the sweeping political changes in Ethiopia through the reports of Ambassador Heinz Langenbacher, the FPD continued its humanitarian and development activities. Later, however, Swiss interests, notably the Duke of Harar Memorial Hospital, were directly targeted. The deposition of the Emperor, which was accompanied by rumours about his assets in Swiss banks, was a turning point for Swiss-Ethiopian relations and soured Bern's links with the new regime. In late 1974, the execution of about 6o high-ranking former dignitaries provoked the Swiss government's first, albeit extremely cautious, public statement on the situation in Ethiopia.

During the early phase of the Ethiopian Revolution, the Swiss authorities observed the situation without taking a stand and were careful not to get involved. Heinz Langenbacher's initial reports on what he considered to be the fiercest incidents of public opposition in the last few years focused on the safety of Swiss citizens and interests in Ethiopia in these "eventful times". ${ }^{23}$ Langenbacher's reports contain no hint of possible Communist activities behind the uprisings. This tallies with a report from the Swiss embassy in Washington from early March, that a State Department official categorically excluded any foreign influence in the revolution. ${ }^{24}$ The majority of foreign diplomats in

23 PR no 8 from Heinz Langenbacher, Swiss ambassador in Ethiopia, "Aethiopien in Bewegung”, 05.03.1974, p. 3, SFA E2300-01\#1977/30\#3*. See also PR no 6 from Langenbacher, "Aethiopien: Erste Bilanz der Unruhen", 25.02.1974, ibid.

24 Telegram no 131 from Felix Schnyder, Swiss ambassador in the USA, "la crise ethiopienne vue de Washington”, o7.03.1974, p. 1, SFA E2001E-o1\#1987/78\#2801*. 
Addis Ababa agreed that the new government appointed as a result of the public protest should be cautiously supported, as divisions within the armed forces made the alternative-a military regime-unattractive. ${ }^{25}$ DPA members were relieved that the Swiss embassy in Ethiopia did not have a radio connection to Geneva and that they could therefore refuse, in mid-March, the imperial family's request to send encoded messages through its diplomatic channels to the Ethiopian Crown Prince, who lived in Geneva for medical reasons. ${ }^{26}$ Despite the uprisings, Bern continued planning an intervention by the newly-founded Swiss Disaster Relief Corps in the famine-affected areas of Ethiopia. ${ }^{27}$

In April 1974, the situation became more alarming from the Swiss government's point of view. Langenbacher reported that both the US, through its stake in the university in Addis Ababa, and the UsSR, through the trade unions, now tried to influence events in Ethiopia. ${ }^{28}$ However, Moscow's reaction to the Ethiopian uprisings was cautious. Soviet and Eastern bloc embassy personnel in Addis Ababa observed the events with great interest, but were careful not to give rise to suspicions that they were supporting leftist extremists. ${ }^{29}$ The civil uprisings in Addis Ababa were also felt in the Duke of Harar Memorial Hospital, which had been opened just a few months before political unrest began to spread and was one of the most important Swiss development cooperation projects on the African continent. In mid-March 1974, a delegation of Ethiopian nursing staff had made a number of complaints to the Ministry of Health. They protested discrimination against Ethiopian staff members and the overly demanding attitude of the Swiss staff and requested more privileges. The Swiss hospital management entered into drawn-out negotiations with the protesters and finally managed to calm the situation..$^{30}$ The Ethiopian press increasingly attacked the hospital, as well as foreign firms and investments. In mid-April,

25 PR no 9 from Heinz Langenbacher, "Kontrolliertes Abwarten in Aethiopien", 12.03.1974, SFA E2300-01\#1977/30\#3*.

26 Letter from Heinz Langenbacher to the DPA, "Unrast in Aethiopien", 19.03.1974, strictly confidential, SFA E2001E-01\#1987/78\#2801*, and handwritten comments on this document.

27 No author (STC), information document, "Informations-Unterlagen zu einer Antwort des Bundesrates an der Sitzung der Sektion 'Politisches Departement' der G PK des NR vom 29. April 1974", 25.03.1974, dodis.ch/39676. PR no 17 from Heinz Langenbacher, "Aethiopien: Agitation und Unrast gehen weiter", 16.04.1974, p. 2, SFA E2300-01\#1977/30\#3*.

29 Yordanov, The Soviet Union and the Horn of Africa, pp. 124-128.

30 Letter from Dr. Johannes Bircher, Swiss hospital management, to the project management in Bern, 01.04.1974, attached to the letter from Heinz Langenbacher to the STC, "Duke of Harrar Spital", 01.04.1974, SFA E2005A\#1985/101\#216*. 
the Council of Ministers considered the introduction of a state monopoly on the import of pharmaceutical products. ${ }^{31}$

From that time onwards, the spectre of nationalisations and other economic measures that threatened Swiss interests in Ethiopia was ever present. The approximately 1,00o workers on the Swiss Bilate cotton plantation went on strike, supported by the union in Addis Ababa. After his negotiations with union representatives and workers failed, the manager contacted the Minister of Interior and had the leaders of the strike arrested. It was not until midMay that work on the plantation resumed. ${ }^{32}$ In late April 1974, a committee of various Ethiopian army and security forces took matters into its own hands and started arresting officials and other representatives of the old regime. Although the committee expressed its allegiance to Haile Selassie's government and soon stopped its activities, Heinz Langenbacher interpreted this as one step further towards military dictatorship. As criticism of the Emperor increased, the ambassador also linked the army's assertiveness to the Portuguese military coup on 25 April that might have served as a model for the Ethiopian army. ${ }^{33}$

On 12 September 1974, Emperor Haile Selassie was arrested and the PMAC officially took power. For Bern, the regime change's most worrying consequence was the accusation made in Ethiopian newspapers, starting in midSeptember, that the deposed Emperor had deposited public funds in Swiss banks. The ensuing bilateral difficulties are discussed later in this chapter. On a legal level, the regime change did not necessitate a direct Swiss reaction. Like France and other Western European states, Switzerland recognises states, not governments. Thus, no official acknowledgement of the regime change was needed. The UK, which does recognise governments, did so in a note one week

PR no 14 from Heinz Langenbacher to Pierre Graber "Weiterhin unruhiges Aethiopien”, 02.04.1974, SFA E2300-O1\#1977/30\#3*; letter from Langenbacher to the Trade Division, "Einfuhr von pharmazeutischen Produkten in Aethiopien", 23.04.1974, SFA E7110\#1985/97\#1850*, letter from Langenbacher to Marcel Heimo, Delegate for Technical Cooperation, "Duke of Harrar Spital in der aethiopischen Presse unter Beschuss", 29.04.1974, SFA E2OO1E-O1\#1987/78\#2799*.

Letter from Heinz Langenbacher to the DPA, "Gefährdung der Plantage unseres Landsmanns Demaurex", 23.04.1974, SFA E2OO1E-o1\#1987/78\#2798*; letter from Langenbacher to the DPA, "Schliessung der Schweizer Plantage Demaurex", 26.04.1974, ibid., letter from Langenbacher to the DPA, "Schliessung der Schweizer Plantage Demaurex", 07.05.1974, ibid., letter from Langenbacher to the DPA, "Schweizer Plantage in Bilate", 14.05.1974, ibid. PR no 19 from Heinz Langenbacher, “Aethiopien: Die Armee greift ein", 29.04.1974, SFA E2300-01\#1977/30\#3*. See also Andargachew Tiruneh, The Ethiopian Revolution, p. 5 O. 
after the arrest of the Emperor. The US government argued that the question of recognition did not arise, and that relations should continue as before. ${ }^{34}$

The Ford Administration's laissez-faire approach to the Ethiopian Revolution disconcerted Swiss policymakers. A few days after the deposition of the Emperor, the Swiss chargé d'affaires in Washington, Olivier Exchaquet, reported that the US government viewed the political changes in Ethiopia in a rather positive light, although the dangers of radicalisation and increased Soviet and Chinese influence were not yet averted. Edward William Mulcahy, Deputy Assistant Secretary of State for African Affairs, told Exchaquet he found it surprising that "the US, whose military and economic assistance of Ethiopia is extremely important, has never been mentioned since the beginning of the slow military revolution; even the CIA, which is readily and often for good reason the target of leftist elements, has never been attacked so far." 35 Although the Derg tried, from its takeover, to enter into an alliance with the Soviet Union, Moscow was, at first, reluctant to improve relations with Ethiopia to an extent that would endanger its ties with Somalia. As long as military assistance from the Soviet Union was not forthcoming, the Derg made sure not to break with the US in order to ensure continued arms supplies. ${ }^{36}$ Mulcahy's positive evaluation of the Ethiopian situation did not reassure Exchaquet. The Swiss chargé d'affaires concluded that the US State Department was so puzzled by the machinations of the Ethiopian generals that it did not even try to understand events that he himself considered to be rather disconcerting. ${ }^{37}$ This is a sign of the progressive lack of confidence of Swiss diplomats in the US government's interpretation of events in Africa and its policies on that continent that would increase over the following years.

On 23 November 1974, the military regime's increasingly harsh treatment of the opposition culminated in the execution without trial of about 6 o former dignitaries of Haile Selassie's government and members of the armed forces. The Derg's chairman, General Aman Andom, was also killed. There was a strong international reaction to these executions, which damaged the Derg's image in many states. On the morning of 26 November, Heinz Langenbacher wired to the FPD that the Derg was planning another series of executions and

34 Note from R. A. Neilson, East African Department (EAD) of the British FCO, to Norman Aspin, Assistant Under-Secretary of State, FCO, "Ethiopia: Recognition of the new military administration", 17.09.1974, TNA FCO 31/1681, and handwritten notes on the document. PR no 85 from Olivier Exchaquet, chargé d'affaires of the Swiss embassy in the US, "Les événements d'Ethiopie vus de Washington", 18.o9.1974, p. 2, SFA E2001-o9\#1984/68\#49*.

36 Westad, The Global Cold War, pp. 262-265.

37 PR no 85 from Olivier Exchaquet, "Les événements d'Ethiopie vus de Washington", 18.og.1974, p. 3, SFA E2001-o9\#1984/68\#49*. 
that the ambassadors of the EEC member states and an ICRC delegate present in Addis Ababa had suggested that their headquarters should send an appeal to the PMAC to respect humanitarian principles. ${ }^{38}$ Fearing for the lives of the imprisoned Ethiopian imperial family, the British, French, and Italian ambassadors in Addis Ababa had indeed taken the initiative to encourage a common EEC appeal to the Derg. London suggested that several African governments should make use of their influence on the Ethiopian regime. The ICRC was first to intervene directly on 26 November, with a telegram to the Derg. The following day, an EEC protest note was handed over. Covered by the EEC petition, the US State Department authorised its chargé d'affaires in Ethiopia to deliver a low-key message to the military government, even though the US was in a vulnerable position due to its long-standing military relationship with Haile Selassie's government. The UN Secretary-General and the President of the UNGA also appealed for clemency. ${ }^{39}$

Before deciding on its own course of action, the FPD requested detailed information about the EEC's plans. The department's secretary general telephoned the neutral governments in Vienna and Stockholm, learning that, while the Austrian government had not yet considered taking a stand, the Swedish authorities planned to join with the other ambassadors in Addis Ababa, support UN appeals, and announce all these actions publicly. ${ }^{40}$ The EEC appeal and the Swedish position figured prominently in the FPD's proposal to the Federal Council that the Swiss government comment briefly on the events in Ethiopia. ${ }^{41}$ This testifies to the department's Western European frame of reference when it came to foreign policymaking on Africa. On 2 December 1974, the

38 Telegram no 342 from Heinz Langenbacher to the FPD, 26.11.1974, SFA E2Oo1E-o1\#1987/ $78 \# 2801^{*}$.

39 Telegram no 578 from Willie Morris, British ambassador in Ethiopia, to the FCO, 26.11.1974, TNA FCO 31/1677; telegram no 574 from Morris to the FCO, 25.11.1974, ibid.; telegram no 575 from Morris to the FCO, 26.11.1974, ibid.; note from M. K. Ewans, EAD, to Norman Aspin, "Ethiopia", 25.11.1974, ibid.; telegram no 702 from James Callaghan, Foreign Secretary, to the British embassies in Kenya, Sudan, Nigeria, Zambia, Ghana, and Tanzania, "Ethiopia", 25.11.1974, ibid.; telegram from Robert Stephen Ingersoll, Deputy Secretary of State, to the US embassy in Ethiopia, 26.11.1974, NARA, RG 59, AAD, CFPF, Electronic Telegrams 1974, 1974STATE261115; telegram from Ingersoll to all US diplomatic posts in Africa, 27.11.1974, ibid., 1974STATE261727; telegram no 21050 from Roger Gallopin, President of the ICRC's Executive Council, to the Provisional Military Government of Ethiopia, 26.11.1974, AICRC B AG 225 072-0o8.

Telegram from Michael Gelzer to the Swiss embassies in the EEC member states, 27.11.1974, urgent, SFA E2OO1E-o1\#1987/78\#2801*; note from Ernesto Thalmann, secretary-general of the FPD, to Gelzer, "Aufruf des Bundesrates an äthiopische Machthaber", 27.11.1974, ibid. Georges-André Chevallaz, Federal Councillor and deputy head of the FPD, proposal to the Federal Council, "Exécutions à Addis-Ababa", 29.11.1974, SFA E2001E-o1\#1987/78\#2801". 
Federal Council broke its official silence about the events in Ethiopia and the policies of the Derg. It published a short statement, expressing its dismay at the loss of life and its hope "that justice and humanity would prevail in Ethiopia and peace return to this country."42 The cautious wording of the statement, which was couched in humanitarian terms, highlights the Swiss authorities' unwillingness to give the impression of interfering in Ethiopia's internal affairs. That they nevertheless decided to go public can be explained, on the one hand, by the interventions of other states that served as examples. On the other hand, and more decisively, the Swiss government was, in early December, under pressure to reveal the state of its diplomatic exchanges with the PMAC concerning the Emperor's assets in Switzerland. Making a public statement about SwissEthiopian relations without mentioning the widely publicised executions in this country would have raised questions, especially as the executions could be used to delegitimise the Derg and its appeals for the repatriation of the Emperor's assets. ${ }^{43}$

The executions of 23 November were a turning point for Ethiopia's foreign relations, and alienated Western and African governments. The press and public opinion in many African states condemned the PMAC's violent policies. According to the US chargé d'affaires, the reactions of African diplomats in Addis Ababa and of OAU officials varied "from revulsion and disgust [...] to regret but cautious hope 'dirg' will now be able to make compromises necessary to unify country." 44 Conscious of Haile Selassie's prestige and worried that the violent events in Ethiopia might tarnish Africa's global image, African diplomats even debated relocating the OAU's headquarters, from where the mass graves of the executed were clearly visible. ${ }^{45}$ The Derg's violent treatment of the opposition also influenced relations with Switzerland. Members of the Ethiopian Foreign Ministry assured Heinz Langenbacher that the PMAC was aware of its humanitarian obligations, that political prisoners would receive a proper trial, and that no more executions would take place. ${ }^{46}$ But while the

42 Information Service of the Federal Chancery, press statement, "Erklärung des Bundesrates", 02.12.1974, SFA E2001E-o1\#1987/78\#2801*.

43 See telegram no 398-40o from Bernard Dufournier, French ambassador in Switzerland, to the French Foreign Ministry, 03.12.1974, CAD 206QO/169.

44 Telegram from [?] Wyman, US embassy in Ethiopia, to the Secretary of State, o2.10.1974, p. 1, NARA, RG 59, AAD, CFPF, Electronic Telegrams 1974, 1974ADDIS14234.

45 Diplomatic report no 4O2/74 from Willie Morris to the FCO, "Ethiopia's bloodless revolution turns bloody: the massacre of 23 November”, o3.12.1974, p. 4, TNA FCO 31/1677; PR no 49 from Heinz Langenbacher, "Militär-Diktatur Aethiopien", o3.12.1974, pp. 2-3, SFA SFA E2300-01\#1977/30\#3*.

46 Letter from Heinz Langenbacher to the DPA, "Der Bundesrat zur Lage in Aethiopien", 03.12.1974, SFA E2OO1E-O1\#1987/78\#2801*. 
Armed Forces Committee adopted a more conciliatory approach after the executions, the Swiss government was, from December 1974 onwards, far less willing to compromise with the Derg, especially when it came to the issue of Haile Selassie's assets in Switzerland.

\section{"Blood Money": Controversy over the Ethiopian Emperor's Swiss Bank Accounts}

After the deposition of Haile Selassie in September 1974, accusations made by the Ethiopian press, and immediately taken up by the public and the Derg, that Swiss banks were harbouring several billion francs that the former Emperor had transferred out of Ethiopia seriously impaired Swiss-Ethiopian relations. The PMAC and the Ethiopian Foreign Ministry subsequently made serious, but ultimately unsuccessful, efforts to gain the Swiss authorities' cooperation to repatriate the Emperor's assets. ${ }^{47}$ The controversy surrounding Haile Selassie's Swiss bank accounts was not unique. Based on documents from the SFA, historian Christophe Farquet identified more than twenty disputes concerning capital flight from Third World countries to Switzerland between the 195os and the $1970{ }^{48}{ }^{4}$ A detailed analysis of how the Swiss political and financial elites collaborated to rebut the Ethiopian accusations and preserve Switzerland's image in that country therefore holds relevance beyond the study of SwissEthiopian relations after the revolution. It also deepens our understanding of Bern's general strategies to protect the banking secret in the Third World. The

A first contribution to the study of this affair has recently been made by El Ammari, Les autorités politiques suisses face aux réclamations d'avoirs illicites.

48 Christophe Farquet, "Au-delà des affaires, de la corruption et de la spéculation. Analyse de la fuite de capitaux vers le nord au temps de la décolonisation au travers des sources diplomatiques suisses", Economic History Working Papers 4 (2017), especially p. 17. On the Swiss banking secret and the role of Swiss banks in the country's foreign policy, see notably Sébastien Guex, "The Origins of the Swiss Banking Secrecy Law and its Repercussion for Swiss Federal Policy", Business History Review 74 (2000), pp. 237-266; Christophe Farquet, La défense du paradis fiscal suisse avant la Seconde Guerre mondiale: une histoire internationale. Analyse de la politique helvétique dans les négociations sur la double imposition et l'évasion fiscale durant l'entre-deux-guerres, Neuchâtel: Éditions Alphil-Presses universitaires, 2016; Peter Hug, "Steuerflucht und die Legende vom antinazistischen Ursprung des Bankgeheimnisses. Funktion und Risiko der moralischen Überhöhung des Finanzplatzes Schweiz", in Jakob Tanner, Sigrid Weigel (eds.), Gedächnis, Geld und Gesetz. Vom Umgang mit der Vergangenheit des Zweiten Weltkrieges, Zürich: vdf Hochschulverlag AG an der ETH Zürich, 2002, pp. 269-321; Marc Perrenoud, "La place financière suisse en tant qu'instrument de la politique étrangère helvétique", Relations internationales 121 (2005), pp. 25-42; Schaufelbuehl, La France et la Suisse. 
analysis remains, however, limited by the lack of sources from the Ethiopian government and from Swiss banks. Although the SBA was an important actor in this controversy, its archives are fragmented and only a single reference to this affair could be found. The study is therefore based almost entirely on Swiss and Western diplomatic sources.

The Emperor's Swiss bank accounts were at the heart of Ethiopian propaganda against Haile Selassie. Immediately before and after his deposition, press reports linked Haile Selassie's investments abroad with the famine in Ethiopia. Switzerland was first explicitly targeted on 15 September 1974, three days after the Emperor was forced to step down. An article published in the English-language newspaper Ethiopian Herald accused the country of having attained its prosperity by benefiting from a poor Third World country:

As for the billions of dollars, it is blood money! Let tiny Switzerland triple its living standards by it, and come back to Africa to help us, a poor underdeveloped country, and modernize our hospitals and selflessly participate in Red Cross and welfare programs because they love us! We don't beg for their aid, we demand our legitimate but stolen money which they kept in their banks with mutual and criminal consent. ${ }^{49}$

The allusion to Switzerland's humanitarian image and especially its support for the Duke of Harar Memorial Hospital rendered the accusation particularly serious. Over the following days, the press continued to promote this connection between Switzerland's financial policies and the suffering of the Ethiopian people, which caused public outrage. The extent to which this press campaign was instigated by the Derg remains unclear.

Swiss embassy personnel in Addis Ababa viewed these press reports with concern and prepared to deal with public demonstrations against Switzerland. ${ }^{50}$ Hans Schärer, in charge of the embassy while Ambassador Langenbacher was on holiday, requested a meeting with Ethiopia's new leader, General Aman Andom, to seek reassurance that the safety of Swiss citizens and interests would be guaranteed. During this meeting, on 23 September 1974, the general told Schärer that he had solid evidence that the Emperor's assets of $\$ 15$ billion

49 Cited in the Letter from Hans Schärer, chargé d'affaires ad interim at the Swiss embassy in Ethiopia, to the DPA, "Aethiopische Geldanlagen in der Schweiz", 16.og.1974, p. 2, SFA E2001E-o1\#1987/78\#1001*.

50 Telegram no 262 from Hans Schärer, Paolo Brogini, and [?] Markstaller to the FPD, 13.09.1974, SFA E2OO1E-O1\#1987/78\#2801*. 
(CHF 45 billion) were invested almost exclusively in Switzerland. ${ }^{51}$ That the Ethiopian head of state was willing to take the time to receive the Swiss chargé d'affaires himself, less than two weeks after the takeover by the Derg and at a time of great political turmoil, testifies to the importance of the issue for the new government. Widespread poverty and famine in Ethiopia meant that the PMAC had great need of additional funds. This episode also refutes the assertion frequently advanced by Western observers critical of the Derg that the accusations against Switzerland served solely to destroy the image of Haile Selassie. Although the vilification of the Emperor certainly served the PMAC's interests, the regime initially had real hope of repatriating the Emperor's funds.

Why was Switzerland singled out in this brazen manner? It could be advanced that this was because the Emperor really did transfer significant sums to Swiss banks, and only Swiss banks. This answer, however, is not sufficient. Although Haile Selassie did indeed have assets in Switzerland, the Derg was never able to prove this, and the sums claimed seem to have been exaggerated. Furthermore, the Derg had access to information that the Ethiopian imperial family had also transferred some capital to other countries, notably the UK and the US. Other additional factors explain why Switzerland was targeted. As the Emperor and his family had close links to Switzerland and it was a known fact that Haile Selassie owned a villa in the country, it was not far-fetched to suspect that he also possessed Swiss bank accounts. From a propaganda point of view, allegations against Switzerland were immediately credible due to the reputation of Swiss banks with their strict interpretation of the banking secret and international headlines about several cases of capital flight from African countries to Switzerland since the early 196os. ${ }^{52}$ Finally, Ethiopian decision-makers certainly preferred to focus the press campaign on a small country with limited political influence, rather than affront the US and the UK at a time when the new regime was still trying to preserve good relations with the Western bloc.

The Derg's hope that the Swiss government would help to repatriate the Emperor's funds proved to be false. Heinz Langenbacher, who broke off his holiday to deal with the affair, was instructed by the deputy chief of the DPA in late September to "draw his Ethiopian interlocutors' attention, in a suitable manner, to the counterproductive effects that the continuation of the unfriendly press campaign against our country might have on all Swiss aid to

Letter from Hans Schärer to the DPA, "Aethiopische Geldanlagen in der Schweiz", 24.09.1974, SFA E2OO1E-O1\#1987/78\#1001*. The sum has been converted to CHF using the exchange rates indicated in Officer, "Exchange Rates Between the United States Dollar and Forty-one Currencies".

Farquet, "Au-delà des affaires", pp. 5-6. 
Ethiopia". ${ }^{33}$ The Swiss government was not above using aid as diplomatic leverage to obtain its priority objective; containment of the rumours. It showed no interest in investigating what truth lay in them. This reaction is representative of what Christophe Farquet called the Swiss "strategy of suppressing and managing crises" when faced with allegations of capital flight. ${ }^{54}$

Ambassador Langenbacher immediately set to work. He met with Ethiopian officials, sent a letter to the approximately 200 Swiss citizens living in Ethiopia in order to reassure them, and planned to publish statements and give interviews to counteract the Derg's propaganda. In early October, he met with Ethiopia's Acting Foreign Minister and the Minister of Information to try and calm the situation. Underlining the damaging effects of the rumours on relations between the two states, Langenbacher handed them a memorandum that explained Switzerland's banking secret and its government's limited means of intervention. While his interlocutors promised to placate the public and the press, they nevertheless insisted on the gravity of the accusations, which the government intended to pursue. ${ }^{55}$ Although the head of the FPD and other high-ranking members of the department were regularly briefed on developments in this affair, ${ }^{56}$ the Swiss ambassador to Ethiopia was largely given free rein to deal with the situation as he saw fit.

While media reports died down after Langenbacher's meeting at the Foreign Ministry, public outrage in Ethiopia continued. Members of the Swiss embassy were verbally and physically attacked. The Swiss team at the Duke of Harar Memorial Hospital experienced increasing hostility from their Ethiopian counterparts. ${ }^{57}$ According to Langenbacher, the Swiss were, in early October 1974, part "of Addis Ababa's most hated foreigners", which was grist to the mill for some OAU diplomats: "They refer to the conduct of Swiss economic circles with regard to Rhodesia and South Africa and assert that Switzerland shows once more its true colours as 'cynical profiteers and hypocrites". 58 In November, the Ethiopian security police interrogated a Swiss businessman, suspect-

53 Michael Gelzer, memorandum, "Aethiopische Geldanlagen in der Schweiz", 30.09.1974, SFA E2OO1E-o1\#1987/78\#1001*.

54 Farquet, "Au-delà des affaires", p. 10.

55 Letter from Heinz Langenbacher to the DPA, "Vermögen des ex-Kaisers bei Schweizerbanken?", 07.10.1974, SFA E7110\#1985/97\#456*; telegram no 296 from Langenbacher to the FPD, 08.10.1974, SFA E2001E-o1\#1987/78\#1001*.

56 Michael Gelzer, handwritten memorandum, 10.10.1974, SFA E2001E-o1\#1987/78\#1001*.

57 Letter from Heinz Langenbacher to the DPA, "Lage in Aethiopien", 15.10.1974, SFA E2001E-o1\#1987/78\#2801*.

58 Letter from Heinz Langenbacher to the DPA, "Vermögen des ex-Kaisers bei Schweizerbanken?", o7.10.1974, p. 5, SFA E7110\#1985/97\#456*. 
ing that he had helped an arrested Ethiopian princess, who was an associate in one of his plantations, to transfer funds to Switzerland. ${ }^{59}$ Aside from the immediate danger to Swiss citizens, the controversy also damaged Switzerland's image, not only in Ethiopia but also on the African continent as a whole.

Reports about the scale of the Emperor's assets in Switzerland were contradictory from the start. The $\$ 15$ billion that Aman Andom had mentioned to Schärer in September 1974 later became 15 billion Ethiopian birr (about CHF 21 billion), several billion birr, or simply a considerable sum. There were also rumours about Haile Selassie's alleged investments in the President Hotel in Geneva and firms like Omega watches and Oerlikon Bührle. In October, Langenbacher heard from a trusted Ethiopian source that the maximum amount the Emperor might have transferred to third countries was CHF 14O-200 million, a sum he seems to have considered plausible. ${ }^{60}$ While the ambassador generally insisted that the amounts mentioned were greatly exaggerated, it is noticeable that he never questioned the basic allegation of capital flight to Switzerland. This is even more striking as the Derg could produce almost no evidence for its claim. After a meeting with General Aman Andom on 10 October, Langenbacher reported that the Derg possessed only a single document attesting to assets of the Emperor in the Industrie- und Handelsbank Zürich. This private bank was founded by industrialist Emil Bührle, Ethiopia's former honorary consul in Zurich. ${ }^{61}$

After this meeting with the chairman of the Derg, Heinz Langenbacher became increasingly pessimistic about the future of Swiss-Ethiopian relations. Fearful of the consequences once the PMAC realised how limited the Swiss government's means - or rather willingness - to intervene really were, the Swiss embassy in Addis Ababa adopted a low profile. In this, Langenbacher enjoyed the moral support of his Western colleagues. They mostly agreed that the Ethiopian claims were exaggerated and purely political, serving to discredit the former Emperor. According to them, the choice of Switzerland, a "traditional country of investments", as a scapegoat served to increase the credibility

59 Letter from Heinz Langenbacher to the DPA, "Feindselige Haltung Schweizern gegenüber", 11.11.1974, SFA E2Oo1E-o1\#1987/78\#2798*; letter from Langenbacher to the DPA, "Jean Demaurex, General Manager der Cafex: Ausreise-Visum", 11.02.1975, ibid.

6o Letter from Heinz Langenbacher to the DPA, "Vermögen des Kaisers in der Schweiz? 14.10.1974, confidential, pp. 1-2, SFA E2OO1E-01\#1987/78\#2799*; letter from Langenbacher to the DPA, "Vermögen des Kaisers", 24.10.1974, p. 1, SFA E7110\#1985/97\#456*.

61 Letter from Heinz Langenbacher to the DPA, "Vermögen des Kaisers in der Schweiz? 14.10.1974, confidential, p. 1, SFA E2001E-o1\#1987/78\#2799*. 
of the allegations. ${ }^{62}$ Although Aman Andom had mentioned to Langenbacher that Haile Selassie also had assets in British and US banks, the Derg never contacted these states' embassies in Ethiopia. This suggests that the Ethiopian regime did not want to antagonise these powerful countries. As Langenbacher wrote to the DPA, the US chargé d'affaires showed much sympathy for Switzerland's difficulties - and disdain for Third World criticism of unlawful Northern practices in the global South: "Incidentally, the American remarked kindly: 'Switzerland and the States have nearly the same problem between myths and emotionalism. You: your banks; we: the CIA!" 63

In mid-October 1974, the Derg raised the stakes and announced that it would send a delegation to Switzerland to discuss the political and legal problems regarding the Emperor's assets. The delegation sought talks with high-ranking members of the FPD and with the president of the SBA. ${ }^{64}$ Fearing retaliatory action against Swiss citizens in Ethiopia, FPD officials tried to convince the SBA to cooperate with the Derg. In a letter to the president of the SBA, Alfred E. Sarasin, the Secretary General of the department underlined the gravity of the situation in Ethiopia and the danger it posed to the security of Swiss nationals living there. Since the presence of the OAU headquarters in Addis Ababa meant that events there had great influence on other African states, he argued that it was in the SBA's own interest to save the reputation of Swiss banks on the African continent. More significantly, he underlined that a show of goodwill was particularly important because the Swiss authorities were, on legal grounds, unable to give information to the delegation, an argument that might be difficult to understand for the Ethiopians. ${ }^{65}$ The Swiss government planned to deal with the Ethiopian delegation in a similar manner to the OAU delegation that had visited Bern in April 1972; to receive it with all honours, but ultimately make no substantial concessions. ${ }^{66}$ During a meeting on 29 October 1974 between the SBA president and high-ranking FPD officials in Bern, a legal

\footnotetext{
$62 \quad$ Ibid., p. 2.

63 Letter from Heinz Langenbacher to the DPA, "Kaiserliches Vermögen in der Schweiz? 18.10.1974, SFA E711O\#1985/97\#456*.

64 Telegram no 300 from Heinz Langenbacher to the FPD, 16.10.1974, SFA E2001E-o1\#1987/ 78\#1001*.

65 Letter from Ernesto Thalmann to Alfred E. Sarasin, President of the SBA, "Relations avec l'Ethiopie concernant les avoirs du Négus en Suisse", 21.10.1974, SFA E2001E-o1\#1987/ $78 \# 1001^{*}$.

66 This link was explicitly made by Ambassador Langenbacher, who argued that the red carpet-treatment had worked very well with the OAU delegation: letter from Heinz Langenbacher to the DPA, "Kaiserliches Vermögen in der Schweiz? 04.11.1974, SFA E711O\#1985/

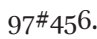


approach to the problem prevailed. The majority of those present agreed that the Ethiopian delegation had to prove its claims and take legal action in order to repatriate possible assets. Alfred Sarasin refused to see the delegation that was scheduled to arrive in mid-November. ${ }^{67}$

Even within the Swiss federal administration, this legalistic interpretation of the Swiss banking secret was not uncontroversial. Two attendees at the meeting advocated a more accommodating position, mainly due to the potential political fallout if Swiss citizens were to suffer because of the activities of the banks. Curt Alfred Markees of the FDJP therefore suggested that the Swiss authorities should make enquiries about the Emperor's accounts in Swiss banks. ${ }^{68}$ The head of the Financial and Economic Service of the FPD, Jean Zwahlen, went even further and called the Swiss banking secret into question. As attacks against Swiss banks for harbouring the assets of politically exposed persons were increasingly frequent and Third World countries critical of Switzerland's banking system had great political weight in international organisations, he argued that the Swiss authorities were constricted by the banking secret. This institution prevented Bern from obtaining the information necessary to deal adroitly with such accusations. As public opinion in Switzerland was also increasingly critical of the banking secret, Zwahlen maintained that banks should be forced to behave more responsibly. He closed his memorandum of the conversation with the sBA delegation by querying whether the Swiss banking secret should really be fully maintained, or whether the revision of Swiss banking law should be considered. ${ }^{69}$ No response to this suggestion is recorded.

In the meantime, the Ethiopian authorities continued to search for proof of the Emperor's assets in Switzerland. The governor of the National Bank of Ethiopia met the imprisoned Haile Selassie several times and went over his books. However, Aman Andom and the Derg were unwilling to accept the banker's

67 Alfred E. Sarasin, W. E. Flückiger, minutes of the 142nd meeting of the Committee of the SBA on 6 November 1974, p. 10, ASBA VRA142Prot_VB; Jean Zwahlen, head of the FPD's Financial and Economic Service, memorandum of conversation, "Avoirs bancaires en Suisse de l'ex-empereur d'Ethiopie. Préparation de la visite d'une délégation éthiopienne, 13.11.1974, SFA E2001E-o1\#1987/78\#1001*; note from Curt Alfred Markees, FDJP, to Kurt Furgler, Federal Councillor and head of the FDJP, "Angeblich in der Schweiz liegendes Vermögen des äthiopischen Kaisers”, urgent, 12.11.1974, SFA E426oC-o1\#1993/9\#411*.

68 Note from Curt Alfred Markees, to Kurt Furgler, "Angeblich in der Schweiz liegendes Vermögen des äthiopischen Kaisers", urgent, 12.11.1974, p. 2, SFA E426oC-o1\#1993/9\#411*.

69 Jean Zwahlen, memorandum of conversation, "Avoirs bancaires en Suisse de l'exempereur d'Ethiopie. Préparation de la visite d'une delegation éthiopienne, 13.11.1974, pp. 2-4, SFA E2OO1E-01\#1987/78\#1001*. 
conclusion that "only a relatively modest amount of money exists", as the British ambassador wrote to the FC ${ }^{70}$ On 15 November 1974, Langenbacher learned from Aman Andom that the former Emperor had signed a power of attorney for the repatriation of his assets and his children had agreed to close their bank accounts in favour of the Ethiopian people. Foreign diplomats in Addis Ababa observed this development with interest. ${ }^{71}$ Yet, doubts soon arose about the existence of this power of attorney. Mohammed Hamid, legal advisor, head of the US desk at the Ethiopian Foreign Ministry, and leader of the Ethiopian delegation scheduled to travel to Switzerland, told Heinz Langenbacher that he had never seen it. Mohammed Hamid, who had just returned from the UNGA, considered the files on the Emperor's assets to be too incomplete to warrant a trip to Bern and therefore postponed it. ${ }^{72}$ The head of the FPD's Directorate of Public International Law (DPIL) was quite content with this postponement. In a personal letter to Heinz Langenbacher, Emanuel Diez explained why the delegation's visit would be fruitless:

We and especially the banks will have to beware of handing over the money, provided that it belongs to the Ethiopian state, to people that might after a short time disappear from the political stage, and the money with them. Because of this fact alone we need to be extraordinarily cautious, also with regard to possible recommendations to the banks, as the Confederation might otherwise later be made directly liable for damages. ${ }^{73}$

The execution of about 60 political prisoners on 23 November 1974 and the subsequent international outcry delegitimised the Derg and weakened its position in the diplomatic exchanges about Haile Selassie's Swiss assets. On the one hand, the Swiss authorities' willingness to collaborate to a certain extent with the PMAC decreased significantly. During a meeting in the presence of Federal

70 Telegram no 536 from Willie Morris to the FCO, 13.11.1974, TNA FCO 31/1676.

71 Letter from Heinz Langenbacher to the DPA, "Vermögen des Kaisers in der Schweiz", 15.11.1974, SFA E711O\#1985/97\#456*; telegram no 541 from Willie Morris to the FCO, 15.11.1974, TNA FCO 31/1676; telegram no 1249 from [?] Treca, French embassy in Ethiopia, to the Foreign Ministry, 15.11.1974, CAD 206QO/169; telegram from [?] Wyman, US embassy in Ethiopia, to the State Department, 15.11.1974, NARA, RG 59, AAD, CFPF, Electronic Telegrams 1974, 1974ADDIS13655.

72 Letter from Heinz Langenbacher to the DPIL, "Kaiserliches Vermögen in der Schweiz?" 18.11.1974, SFA E711O\#1985/97\#456*.

73 Letter from Emanuel Diez, head of the DPIL, to Heinz Langenbacher, 22.11.1974, personal and confidential, SFA E2001E-o1\#1987/78\#1001*. 
Councillor Pierre Graber a few days after the executions, DPA leaders decided that it was not opportune to receive an Ethiopian delegation as long as the situation in Addis Ababa was "troubled, confused, and chaotic" and as long as the emissaries' mandates and their duration was called into doubt because of the government's fragility. ${ }^{74}$ While the executions served as a welcome pretext to those voices within the FPD that had never wanted to enter into negotiations with the Ethiopian authorities, they also silenced internal calls for some degree of collaboration and a more flexible approach to the banking secret. Meanwhile, possibly as a result of statements made by London-based members of the Ethiopian imperial family after the executions, information about the proposed visit of the delegation leaked to the international press. ${ }^{75}$ This increased the pressure on the Derg to be able to show some positive results from the affair of the former Emperor's assets.

During a press conference on the same day as the publication of the Federal Council's statement on the executions in Ethiopia, the Swiss Vice Chancellor announced the planned visit of the Ethiopian delegation. ${ }^{76}$ As a result of the ensuing publicity, National Councillor Jean Ziegler (Social Democratic Party) asked the government in a parliamentary interpellation to insist that Swiss banks return the Emperor's assets to the Ethiopian people, as the affair risked harming Switzerland's relations with OAU member states. ${ }^{77} \mathrm{He}$ was not heeded. On the contrary, the FPD's attitude had hardened considerably. In a telegram to Langenbacher, Emanuel Diez no longer mentioned political factors, such as the possibility of reprisals against Swiss citizens in Ethiopia, but argued firmly, using legal phraseology. He insisted that the Derg needed to give precise information about the sums concerned and the banks involved if it wanted to have any chance of recovering the assets. Diez suggested that the PMAC engage a Swiss lawyer to follow up on its claims. This was even more advisable, since, as he put it, the Swiss legal system was difficult to grasp for non-European legal experts. ${ }^{78}$

74 Telegram no 256 from Michael Gelzer to the Swiss embassy in Ethiopia, 26.11.1974, SFA E2001E-o1\#1987/78\#1001*.

75 Telegram no 347 from Heinz Langenbacher to the FPD, 27.11.1974, SFA E20o1E-o1\#1987/ $78 \#_{1001}{ }^{*}$; letter from Langenbacher to the Information and Press Service of the FPD, "Vermögen des Kaisers", 28.11.1974, confidential, SFA E7110\#1985/97\#456*.

76 Telegram no 273 from Peter Erni, head of the F PD's Information and Press Service, to the Swiss embassy in Ethiopia, o2.12.1974, SFA E2001E-01\#1987/78\#2801*.

77 "Interpellation Ziegler-Genève. Gelder aus Aethiopien. Wortlaut der Interpellation vom 4 Dezember 1974", Amtliches Bulletin der Bundesversammlung 1975, Wintersession Nationalrat, 01.12.1975, p. 1545 .

78 Telegram no 285 from Emanuel Diez to the Swiss embassy in Ethiopia, 06.12.1974, SFA E2001E-01\#1987/78\#1001*. 
After the killing of General Aman Andom in Ethiopia, the alleged power of attorney signed by Haile Selassie could not be found. Both Mohammed Hamid of the Foreign Ministry and Major Mengistu Haile Mariam, the Derg's "strongman", to use Langenbacher's words, and future Ethiopian head of state, independently asked the Swiss ambassador to visit the former Emperor in prison and witness his signature on a new document. ${ }^{79}$ This was the first, albeit indirect, contact between the Swiss authorities and Mengistu. DPA leaders did not approve of this idea, as Langenbacher's presence was no guarantee that the prisoner was not signing under duress and it was doubtful that the banks would accept the legitimacy of the document. Out of concern for the safety of Swiss citizens in Ethiopia, they did not reject the proposal outright, but ordered Langenbacher to do his best to avoid being mixed up personally in the affair. ${ }^{80}$ The Ethiopian authorities' somewhat rash proposal was probably a result of their dismay at the international protests following the executions. In any case, it was not followed up. On 30 November 1974, the Derg publicly announced that the Emperor had agreed to transfer his own and his family's assets to Ethiopia in favour of the famine-stricken areas. The Emperor's letter, which was dated 18 October 1974, no longer singled out Switzerland, but rather mentioned transfers to banks outside of Ethiopia more generally. ${ }^{81}$

In mid-December 1974, the rumours about Haile Selassie's Swiss bank accounts died down and the Derg stopped making demands. In the following months, the Ethiopian authorities hardly ever mentioned the affair. Two factors explain the PMAC's silence: on the one hand, the Derg was busy with the conflict in Eritrea-after the violent death of General Aman Andom, himself Eritrean, hostilities between government troops and liberation movements escalated in this province; on the other hand, a copy of a Swiss Federal Court verdict in a similar case of capital flight had opened the Ethiopian authorities' eyes to the difficulties they faced in seeking repatriation of the funds. In July 1974, the Federal Court had, in fact, set aside an earlier cantonal judgment in favour of the restitution to the Algerian government of funds deposited in

79 Heinz Langenbacher, memorandum, "Vermögen des Kaisers", 28.11.1974, attached to the letter from Langenbacher to the DPIL, "Kaiserliches Vermögen", 28.11.1974, confidential, SFA E711O\#1985/97\#456*.

8o Telegram no 272 from Ernesto Thalmann to the Swiss embassy in Addis Ababa, 29.11.1974, SFA E2001E-o1\#1987/78\#1001*; telegram no 329 from Thalmann to the Swiss embassy in Paris, for the attention of Pierre Graber, 29.11.1974, urgent, ibid.

81 Cited in the letter from Heinz Langenbacher to the DPIL, "Vermögen des Kaisers", o9.12.1974, confidential, p. 1, SFA E7110\#1985/97\#456*; see also letter from Langenbacher to the DPIL, "Vermögen des Kaisers", o3.12.1974, confidential, ibid. 
Swiss banks by the former Secretary General of the FLN ${ }^{82}$ Although the governor of the National Bank of Ethiopia seems to have been in contact with a bank in Zurich, ${ }^{83}$ it appears that the Derg had given up hope that Swiss banks would agree to repatriate the former Emperor's assets.

By the time Heinz Langenbacher took his leave from the Ethiopian government in mid-May 1975, a slow normalisation of bilateral relations had taken place. The ambassador was optimistic that, with suitable Swiss humanitarian and development aid, the issue of the Emperor's assets in Switzerland might be laid to rest. ${ }^{84}$ Half a year later, the governor of the National Bank of Ethiopia confirmed in a discussion with Langenbacher's successor, Olivier Exchaquet, that the affair was now forgotten. ${ }^{85}$ In Switzerland, Federal Councillor Georges-André Chevallaz's verbal reply to Jean Ziegler's request concluded the discussion about this issue in early December 1975. The head of the FDF refused to intervene in the affairs of third states by determining whether a head of state's assets in Switzerland were legally acquired. Alluding to the portrayal of the Swiss banking secret in popular films and books, Chevallaz expressed his unwillingness to be the "James Bond' of international justice", thereby dismissing calls for the Swiss government to take a more active role with regard to capital flight. ${ }^{86}$

What was the truth behind the allegations about the Ethiopian Emperor's assets in Swiss banks? Historian Christophe Farquet qualifies the evidence for capital flight from Ethiopia to Switzerland as adequate. ${ }^{87}$ Although it is impossible, in the absence of data from the concerned banks, to determine the precise sums that Haile Selassie or his family deposited in Swiss banks, there is

82 Letter from Heinz Langenbacher to the DPIL, "Kaiserliches Vermögen", confidential, 03.02.1975, SFA E2001E-01\#1987/78\#1001*. See also the letter from Langenbacher to the DPIL, “Kaiserliches Vermögen”, confidential, 10.01.1975, ibid.; Bahru Zewde, A History of Modern Ethiopia, p. 257, Farquet, "Au-delà des affaires", p. 12.

83 Letter from Heinz Langenbacher to the DPIL, "Kaiserliches Vermögen", confidential, O3.03.1975, p. 1, SFA E2OO1E-01\#1987/78\#1001*.

84 Letter from Heinz Langenbacher to Pierre Graber, "Unsere Beziehungen zu Äthiopien”, 20.05.1975, SFA E2001E-01\#1987/78\#1001*.

85 Letter from Olivier Exchaquet, Swiss ambassador in Ethiopia, to the DPA, "Besuch Gouverneur Staatsbank", o6.11.1975, SFA E2001E-o1\#1987/78\#2787*.

86 Statement by Georges-André Chevallaz, Federal Councillor and head of the F DF, "Interpellation Ziegler-Genève. Gelder aus Aethiopien”, Amtliches Bulletin der Bundesversammlung 1975, Wintersession Nationalrat, 01.12.1975, p. 1547. On this subject, see Sébastien Guex, Gianni Haver, "James Bond contre - ou pour? - les gnomes de Zurich. L'image de la place financière suisse dans da série oo7", in Françoise Hache-Bissette, Fabien Boully, Vincent Chenille (eds.), James Bond (2)oo7. Anatomie d'un mythe populaire, Paris: Bélin, 2007, pp. 330-338.

87 Farquet, "Au-delà des affaires", p. 17. 
no reason to doubt that the imperial family had indeed transferred money to Switzerland before the deposition of the Emperor. The Swiss authorities never questioned this. On the contrary, when the Ethiopian court had asked Langenbacher in the early days of the revolution about a secure radio connection to Geneva, observers in Bern immediately concluded that the imperial family wished to transfer its assets to Switzerland. ${ }^{8}$ They did not, however, envisage taking any steps to prevent this. Two sources offer more positive proof. In May 1975, the deputy chief of the DPA heard from reliable Swiss sources connected to the imperial family that, although several major and private banks in Geneva and Zurich had denied the existence of bank accounts in Haile Selassie's name, the Industrie- und Handelsbank Zürich administrated "relatively small assets of the Emperor".89 This tallies with the report of a luncheon conversation between the US ambassador in Switzerland and several prominent Geneva bankers in early December 1974. During this discussion, the bankers acknowledged that the former Emperor certainly had assets in Switzerland, although they were not nearly as substantial as reported in the press. Having met Haile Selassie in the 1930s, the senior manager of the Geneva branch of "one of the largest Swiss banks" reportedly "expressed doubt that he [the Emperor] had financial sophistication personally to make wide use of possibilities offered in Switzerland," as a member of the US embassy in Switzerland reported to the State Department. ${ }^{90}$

Whatever the scale of the imperial family's assets in Switzerland, the allegations made by the Ethiopian press and authorities were based in fact. Confronted by accusations of benefiting economically from the pillage of a poor Third World country, the Swiss authorities fell back on their standard reaction when confronted with cases of capital flight: they focused on smoothing things over and hid behind the legal framework by demanding exact proof and stressing their independence from, and lack of influence on, Swiss banks.

Why did the controversy die down? The fall and eventual end of Ethiopian demands for the restitution of Haile Selassie's assets was not a result of political or economic pressure from the Swiss government. Switzerland's economic interests in Ethiopia were few and the Swiss involvement in the Duke of Harar Memorial Hospital provided limited leverage over the Derg. It is more probable

88 Handwritten comment on the letter from Heinz Langenbacher to the DPA, "Unrast in Aethiopien", 19.03.1974, strictly confidential, SFA E2001E-o1\#1987/78\#2801*.

89 Jürg Andreas Iselin, deputy chief of DPA and chief of its African, Asian, Middle Eastern and Latin American Division, memorandum, "Aethiopien, kaiserliches Vermögen", 28.05.1975, p. 2, SFA E2001E-o1\#1987/78\#1001*.

9o Telegram from [?] Percival, US embassy in Switzerland, to the State Department, 05.12.1974, p. 2, NARA, RG 59, AAD, CFPF, Electronic Telegrams 1974, 1974BERNo4556. 
that the controversy abated because the Derg, once its leaders realised that it would be difficult to recover Haile Selassie's assets through the Swiss courts due to the lack of both evidence and Swiss government cooperation, decided to focus its attention on more immediate problems: the widespread internal opposition to its regime, the escalating conflict in Eritrea, and the transformation of Ethiopia's economy. Nonetheless, the issue of the former Emperor's Swiss bank accounts continued to overshadow all aspects of Swiss-Ethiopian relations in the following years.

"The Situation Is Likely to Deteriorate Further": Economic and Humanitarian Relations with Pro-Soviet Ethiopia

Ambassador Heinz Langenbacher's belief that the political and economic situation in Ethiopia was likely to deteriorate after his departure in May 1975 was correct. ${ }^{91}$ As soon as Haile Selassie's Swiss bank accounts disappeared from the political agenda, two new issues cast a shadow over Swiss-Ethiopian relations: the nationalisation of Swiss assets in Ethiopia and Switzerland's gradual withdrawal from the Duke of Harar Memorial Hospital. The Swiss embassy in Addis Ababa and the authorities in Bern continued to keep a low profile. The issue of the Emperor's assets in Switzerland was frequently mentioned in discussions about how to obtain compensation for nationalised Swiss property and whether development aid to Ethiopia should be continued, and care was taken not to further alienate the Ethiopian authorities. As the controversy might flare up again at any moment, Bern had limited leverage to protect the interests of Swiss citizens. Between 1974 and 1976, as the PMAC strengthened its links with the USSR, Switzerland's economic and humanitarian presence in Ethiopia dwindled.

The Ethiopian Revolution cut short the country's nascent development cooperation partnership with Switzerland. Given the size of the Swiss engagement, it was the hospital project that was most affected by the political and military turmoil. After the deposition of Haile Selassie in September 1974, the latent tensions between the European and Ethiopian staff of the hospital flared up again. The leader of the Swiss medical delegation feared that Swiss team members might be kidnapped to force Bern to cooperate in the repatriation of the Emperor's holdings in Switzerland. The Swiss team faced increasing

91 Heinz Langenbacher, final report, "Schlussbericht: Pendente Fragen und Hinweise", 14.04.1975, p. 3, attached to the letter from Langenbacher to the AD, "Schlussbericht", 14.04.1975, SFA E2OO1E-o1\#1988/16\#3164*. 
resentment from Ethiopian staff and patients. In early December, the hospital even had to be briefly evacuated after a bomb alert. As a consequence, morale was low. ${ }^{92}$ Members of the Derg criticised the hospital project for not being adapted to local conditions, since they considered it more important to train a large number of basic health operators for the countryside rather than a few highly skilled specialists. The Duke of Harar Memorial Hospital, it was declared, should become a real 'hospital for the people. ${ }^{93}$

The members of the Swiss project management team at the University of Bern were disheartened by this growing hostility and advocated the accelerated handover of the hospital; Swiss staff should be gradually replaced with Ethiopian staff and responsibilities handed to the Ethiopian side. ${ }^{94}$ In early December 1974, the dean of the medical faculty of the University of Bern announced the project management's intention to terminate its participation in the hospital project by 30 June 1975. This decision was justified by the faculty's conviction that, due to the changes in Ethiopia, the main objectives of the project - especially the teaching of Ethiopian healthcare specialistswere unattainable. ${ }^{95}$ The withdrawal of the Swiss project management team forced the FPD to decide if and how Swiss support for the hospital should be continued. The sTC, which had initially had the biggest reservations about the project, advocated the continuation of Switzerland's engagement. As the biggest personnel and financial contributions that the Swiss authorities had ever made to a single project phase were at stake, and premature discontinuation might renew the controversy over the Emperor's assets in Switzerland, the new Delegate for Technical Cooperation argued that the project should not be abandoned completely. ${ }^{96}$ During an interdepartmental meeting on the future of the hospital in late January 1975, domestic arguments to continue were decisive. Federal Councillor Pierre Graber insisted that, although the initial deci-

92 Letter from Johannes Bircher to the STC, 23.09.1974, confidential, SFA E2001E-o1\#1987/ $78 \# 2798^{*}$; letter from Heinz Langenbacher to the DPA, "Vermögen des Kaisers in der Schweiz? 14.10.1974, confidential, SFA E20o1E-o1\#1987/78\#2799*; telegram no 365 from Langenbacher to the FPD, 03.12.1974, ibid.

93 Letter from Heinz Langenbacher to the sтc, "Konzept des Duke of Harrar Spitals", 24.10.1974, SFA E2005A\#1985/101\#216*.

94 Letter from Walter Mamie, Swiss project management, to the STC, "Projekt Duke of Harrar Memorial Hospital, Addis Ababa", 16.10.1974, SFA E2005A\#1985/101\#216*.

95 Letter from Jürg Hodler, dean of the medical faculty of the University of Bern, to Pierre Graber, "Projet Duke of Harrar Memorial Hospital Addis Ababa", 05.12.1974, SFA E2001E-01\#1987/78\#2799*.

96 Note from Rolf Wilhelm, Vice-Director of the sTc, to Pierre Graber, "Duke of Harrar-Spital Addis Abeba. Kündigung des Regievertrages durch die medizinische Fakultät der Universität Bern vom 17. Januar 1975", 23.01.1975, p. 1, SFA E2001E-o1\#1987/78\#2799*. 
sion to support the project had been a mistake, it was now crucial to save face at a time when development aid was much criticised by politicians and the general public. ${ }^{97}$ Graber's words alluded to a draft law on humanitarian and development aid that had been debated in the Swiss parliament since 1971. Newspaper headlines about the waste of taxpayers' money in Ethiopia were liable to reduce the likelihood of the law being passed. ${ }^{98}$

While the FPD prepared to shoulder responsibility for the hospital on its own, it also had to deal with the nationalisation of Swiss assets in Ethiopia. On 6 December 1974, two weeks after the widely publicised executions, the new chairman of the Derg, Teferi Bante, had outlined the policy guidelines of his government to a delegation of the diplomatic corps. Apart from the Derg's commitment to human rights, which Heinz Langenbacher received with some scepticism, Teferi Bante's promise that the PMAC did not envisage the nationalisation of foreign property and, on the contrary, welcomed foreign investment in Ethiopia, drew his attention. This contradicted reports that nationalisations were imminent in Eritrea. ${ }^{99}$ Indeed, the chairman's promise proved to be short-lived. On 1 January 1975, the Derg enacted a first wave of nationalisation, taking over all banks, financial, and insurance companies. One month later, 72 more firms were nationalised, followed by farmland in March. ${ }^{100}$ Historian Andargachew Tiruneh argues that the Derg made these decisions less in the hope of economic gain for the Ethiopian state than in an attempt to appear progressive and win over the civilian left by carrying out the reforms demanded during the popular uprisings in early $1974 .{ }^{101}$ The most important nationalisations of Swiss property occurred in the insurance and agricultural sectors. The

97 Noa Zanolli, sTC, memorandum, "Zusammenfassung der Besprechung mit Bundespräsident Graber. Fortführung Duke of Harrar-Spital”, 30.01.1975, SFA E2001E-01\#1987/78\#2799*; telegram no 26 from Marcel Heimo to the Swiss embassy in Ethiopia, 04.02.1974, SFA E2005A\#1985/101\#216*.

98 Because both leftist and conservative factions contested it vigorously, this law was only adopted in 1976: Waldburger, Zürcher, Scheidegger, 'Im Dienst der Menschheit', pp. 85-87.

99 Letter from Heinz Langenbacher to the DPA, "Erster Besuch beim neuen Staatschef", o9.12.1974, confidential, SFA E2Oo1E-o1\#1987/78\#2801*; PR no 51 from Langenbacher, "Erste Erklärung des neuen Chairman Teferi", 16.12.1974, SFA E230o-o1\#1977/30\#3* and the attached document, "Statement of H.E. Brigadier General Teferi Banti to deans of the diplomatic corps on Dec. 6, 1974".

100 Letter from Heinz Langenbacher to the DPIL, "Nationalisierungsmassnahmen der aethiopischen Militär-Regierung”, o6.o1.1974, SFA E2001E-o1\#1987/78\#2787*; letter from Langenbacher to the DPA, "Weitere Nationalisierungen in Aethiopien", 04.02.1974, ibid.; letter from Henning Rieder, chargé d'affaires ad interim in the Swiss embassy in Ethiopia, to the DPA, "Nationalisierung des Ackerlandes", 10.03.1974, ibid.

Andargachew Tiruneh, The Ethiopian Revolution, p. 96. 
re-insurance company Swiss Re held $16.5 \%$ of the share capital of the nationalised African Solidarity Insurance Co., worth CHF 680,0oo, and had concluded reinsurance contracts with several other Ethiopian insurance companies. ${ }^{102} \mathrm{~A}$ number of plantations, as well as some smaller interests, were also affected. Compared to other states, Swiss damages were limited. With 3.4\% of all nationalised foreign interests, Switzerland occupied the fifth rung of affected states, after Italy $(55 \%)$, the Netherlands $(20 \%)$, the US $(7 \%)$, and the UK $(5 \%) .{ }^{103}$

The DPA, which was responsible for dealing with nationalisations, immediately charged the Swiss ambassador in Addis Ababa with documenting every case of Swiss interests affected by the actions of the Derg. ${ }^{104}$ Like his EEC colleagues, Heinz Langenbacher sent a protest note to the Derg in mid-February, insisting on fair compensation for nationalised Swiss interests. However, the Ethiopian authorities had only just established a commission to draft the law that would serve as the legal basis for nationalisations. Since there was much uncertainty about the country's future economic policy, the DPA decided to wait until the situation in Ethiopia had calmed down. ${ }^{105}$ Langenbacher's demarches to the Ethiopian authorities were somewhat isolated. In early 1975, the ambassadors of EEC member states in Addis Ababa met frequently to coordinate their action. In a collective note to and during meetings with members of the Ethiopian government, they insisted on prompt, adequate, and effective compensation. There was also some coordination with the Japanese, Indian, and Greek ambassadors, as well as the US chargé d'affaires. Heinz Langenbacher was not included in meetings open to non-EEC members. In a despatch to the FCO in May 1975, the British ambassador underlined the benefits of this cooperation: "I am in no doubt that this demonstration that we work together-and the implicit reminder of our collective importance to Ethiopia - strengthens our position." ${ }^{106}$ If the Ethiopian authorities had, in the

102 Letter from P. Gmeiner, secretary of the Swiss Insurance Association, to the Financial and Economic Service of the FPD, "Nationalisierung in Aethiopien", 23.01.1975, p. 1, SFA E2001E-o1\#1987/78\#2787*.

103 Andargachew Tiruneh, The Ethiopian Revolution, p. 94. This is based on data from the Ethiopian Compensation Commission for nationalisations, which does not, however, indicate the value of assets nationalised.

104 Letter from Alfred Reinhard Hohl, DPA, to the Swiss embassy in Ethiopia, 10.01.1975, SFA E20o1E-o1\#1987/78\#2787*.

105 Letter from Heinz Langenbacher to the DPA, "Nationalisierungen in Aethiopien", 26.02.1975, SFA E2001E-o1\#1987/78\#2787*.

106 Despatch from Willie Morris, British ambassador in Ethiopia, to James Callaghan, Foreign Secretary, "Nationalisations in Ethiopia", 19.05.1975, confidential, p. 11, TNA FCO 31/1845; see also the letter from Morris to Richard A. Neilson, EAD, "Nationalisations", 27.02.1975, TNA FCO 31/1844. 
1970s, started to pay compensation for nationalised interests, it is possible that collective action would have brought about speedier results. As this was not the case, the question of whether Switzerland's non-membership of the EEC was, in this instance, a disadvantage remains open.

Ethiopia's political instability and nationalisation policy discouraged foreign investors. In order to stop the brain drain that increased after the nationalisations of early 1975, the Derg refused to grant exit visas to thousands of foreign citizens. This affected very few Swiss citizens. While a missionary was allowed to depart if he promised not to return, two businessmen later left the country illegally. ${ }^{107}$ As the Ethiopian authorities did not have the manpower necessary to effectively take over control of nationalised firms, many of them continued to muddle along under their old management and save what could be saved. By September 1975, neutral and Western governments had still not received any reply to their various demarches to the Derg but agreed to wait and see. For domestic reasons, the US State Department was particularly patient. As the Hickenlooper amendment allowed the discontinuation of economic and military aid programmes to states that had nationalised US interests without offering due compensation, the US embassy kept a low profile in order to keep Congress from stopping arms deliveries to Ethiopia. ${ }^{108}$

Swiss firms and individuals affected by nationalisations in Ethiopia adopted various strategies. Large companies with interests in many states could afford to be patient and seem to have preferred to deal directly with the local authorities. Conversely, the owners of small firms whose economic existence was threatened by the nationalisation of their investment relied heavily on the DPA's support. The heads of the re-insurance company Swiss Re took matters into their own hands. After a first, unsuccessful, attempt to negotiate with the Ethiopian authorities in Addis Ababa in early 1975, they appealed to the regime for compensation in December of that year, requiring no help from the DPA. ${ }^{109}$

107 Letter from Heinz Langenbacher to the DPA, "Ausreise- und Visa-Verweigerung", 28.02.1975, SFA E2OO1E-o1\#1987/78\#2789*; note from Langenbacher to the Swiss embassy in Ethiopia, "ввС Baden in Aethiopien", о2.06.1975, confidential, attached to the letter from Rolf Heinis, DPA, to the Swiss embassy in Addis Ababa, "ввс Baden in Aethiopien", 10.06.1975, SFA E2001E-o1\#1987/78\#2778*.

108 Letter from Olivier Exchaquet, Swiss ambassador in Ethiopia, "Nationalisations", 17.09.1975, SFA E2Oo1E-o1\#1987/78\#2787*; see also airgram from [?] Hummel, US embassy in Ethiopia, “American Firms Nationalized by Ethiopian Government", 05.09.1975, NARA, RG 59, P-Reel Printouts 1975, P750148-o928, box 148B.

109 Letter from Swiss Re to the FPD, "Nationalisierung in Aethiopien - African Solidarity Ins. Co., Addis Abeba", 05.12.1975, SFA E7110\#1986/24\#1248*, and the attached letter from Swiss Re to the Ethiopian Ministry of Commerce and Industry, "The African Solidarity Insurance Co. Ltd., Addis Ababa", 05.12.1975. 
The pharmaceutical firm Ciba-Geigy also took quick, preventive action. In the light of the danger that its Ethiopian agent, foreign controlled Ageca, might be nationalised, the group's executive committee agreed in March 1975 to open a technical advisory office in Addis Ababa. This allowed technicians stationed in Ethiopia to continue promoting Ciba-Geigy products. In the following years, the technical advisory office, which was not formally registered in Ethiopia, operated from Ageca's premises, while its employees were contracted by CibaGeigy's regional office in Nairobi. ${ }^{110}$

The DPA was much more closely involved in the case of the nationalised plantations and firms managed by Swiss businessman Jean Demaurex. He had founded three businesses in Ethiopia, two of which, Tana Plantation Co. and Bilate Agricultural Estate, were controlled by André \& Cie, which held a majority interest of CHF 24 million. These two plantations were nationalised in March $1975 .{ }^{111}$ For investments in Bilate plantation amounting to $\mathrm{CHF}$ 4.2 million and resulting interest revenues, Jean André had obtained, in June 1973, an investment risk guarantee (IRG) with a risk coverage of $70 \%$. After the nationalisation of his two plantations, André demanded his dues from the Swiss state. ${ }^{112}$ In July 1976, the IRG Commission and the head of the FDEA decided to disburse the guaranteed amount to Jean André. ${ }^{13}$ This meant that the DPA was now responsible for recuperating the losses engendered by the

110 A. Baumgartner, minutes no 12/75 of the Ciba Geigy Group Executive Committee meeting on 25 March 1975, Novartis archives, Basel, Switzerland, Ciba-Geigy company archives, minutes: minutes of the Group Executive Committee, box KL.1; note from H. Schwarb, Region 5 (Africa), to M. Wertenschlag and B. Sygfrid, "Aethiopien / Registrierung TAO CGTMS", 25.10.1978, ibid., regional services, box RD 07.2, and the attached letter from P. J. Wanner, W. F. Grieder, regional office Nairobi of Ciba-Geigy Trading and Marketing Services Co., Ltd., to M. Werdenschlag, Ciba-Geigy Ltd., Basel, “T.A.O. Ethiopia”, 16.10.1978.

111 Letter from Heinz Langenbacher to the DPA, "Nationalisierungen", 20.03.1975, SFA E7110\#1986/24\#1248*; letter from Langenbacher to the DPA, "Nationalisierungen: Billate Plantation", 27.03.1975, ibid.

112 Claude Hugenin, DPA, memorandum "Garantie contre les risques de l'investissement: cas André / Ethiopie", 03.07.1975, SFA E2001E-01\#1987/78\#2787*; M. Heini, audit expert in the Swiss Federal Audit Office, report, "Bericht über die Aktenprüfung im Zusammenhang mit dem I RG-Schadenfall Nr. 73.2.1, Aethiopien; Billate Agricultural Estate", o9.01.1976, SFA E7110\#1987/2O\#1202*. The IRG, introduced in 1970, aims to promote Swiss investments in developing countries. Although its introduction was frequently justified with development objectives, its main beneficiaries were Swiss investors: see Chantal Magnin, "Entwicklungshilfe für die Schweizer Wirtschaft. Der lange Weg zur Investitionsrisikogarantie, 196o-197o”, in Hug, Mesmer, Von der Entwicklungshilfe zur Entwicklungspolitik, pp. 363-379.

113 Letter from Ernst Brugger, Federal Councillor and head of the FDEA, to the IRG Commission, "Investitionsrisikogarantie / Schadenfall auf Verfügung Nr. 73.2.1 Aethiopien, André, Lausanne", o1.07.1976, SFA E7001C\#1987/101\#539*. 
plantations' nationalisation and recovering the disbursed sum from the Ethiopian authorities. Demaurex' own firm, Cafex, was taken over by the PMAC after its owner illegally left Ethiopia in August 1975, having waited almost a year for an exit visa. However, as he did not have an IRG cover, the DPA argued that responsibility for obtaining compensation remained with the owner. ${ }^{114}$

Swiss-Ethiopian cooperation in the humanitarian field was no more satisfactory than in the economic sphere. In mid-1975, the Swiss and Ethiopian authorities agreed on a limited continuation of the hospital development project. While the running of the hospital was handed over to the Ethiopians, the STC agreed to recruit and pay six medical specialists that would work and teach in Addis Ababa for another 18 months. The suggestion, made by a member of the Ethiopian Ministry of Health, that the Swiss authorities should put the sum remaining in its project budget at the disposal of the ministry — which could recruit two doctors from the Eastern bloc for the salary of one Swiss specialist-received a non-committal response. ${ }^{115}$ By late November 1975, the reminder of Ethiopia's imperial past had disappeared from the name of the hospital, now known as Black Lion Hospital. However, collaboration with the Ethiopian authorities did not become any easier. The STC struggled to obtain replies to its repeated queries and conditions did not permit the doctors it had recruited to fulfil their teaching duties. In April 1976, the Derg sent all the newly-trained anaesthetists and 15 anaesthesia machines paid for by the STC to aid the war effort in Eritrea. The Swiss authorities reacted by withdrawing one of its doctors from the hospital. As the main objective of the three remaining doctors' expert mission in Addis Ababa - teaching — had become almost impossible, the STC decided in November 1976 not to continue its limited involvement in Ethiopia. ${ }^{116}$ This was the end of Switzerland's support for the former Duke of Harar Memorial Hospital. Collaboration with Ethiopia would,

114 ATS/DPA, “Un Lausannois arrêté en Éthiopie", Tribune - Le Matin, o9.08.1975, p. 7; telegram no 181 from the Swiss embassy in Addis Ababa to the FPD, SFA E2Oo1E-o1\#1987/78\#2798*; Claude Huguenin, memorandum, "Visite de M. et Mme Jean Demaurex, le 22 août 1975", 22.08.1975, SFA E2OO1E-o1\#1987/78\#2798*.

115 Noa Zanolli, memorandum of conversation with Dr. Assefa Tekle, Permanent Secretary of the Ethiopian Ministry of Public Health, and Ato Mengesha, head of the ministry's planning department, 05.06.1975, SFA E2005A\#1985/101\#216*; Letter from Marcel Heimo to the Swiss Embassy in Ethiopia, "Fortsetzung der Schweizer Hilfe. Unsere beiden Noten vom 1. April 1975", 17.07.1975, ibid.

116 Noa Zanolli, report, "Bericht über Dienstreise vom 17.10.75-16.11.75 nach Tansania und Aethiopien von N. Zanolli”, 26.11.1975, p. 44, E2005A\#1985/101\#216*; letter from Olivier Exchaquet, Swiss ambassador in Ethiopia, to the Delegate for Technical Cooperation, 26.04.1976, p. 2, SFA E2005A\#1991/16\#523*; letter from Exchaquet to the sTC, "Black Lion Hospital”, 17.05.1976, p. 1, SFA E2005A\#1991/16\#523*; letter from Jean-Maurice Délèze, STC, 
in any case, have come to an end in 1977, when the Derg forced all Western doctors and medical personnel to leave the country.117

The results of almost six years of development cooperation with the Ethiopian authorities were mixed. Pressured into taking on a project that did not meet its criteria for medical aid, the STC was often forced to improvise. While some of the problems that arose at the hospital might have been avoided through better planning that took Ethiopian needs into account, the project can reasonably be called a victim of the Ethiopian Revolution. Although Swiss involvement in the hospital provided medical equipment and care to a country that lacked both, anti-Western and especially anti-Swiss sentiments in Ethiopia had a disruptive effect on work in the hospital. The resulting frustration explains why, in mid-1981, the Vice-Director of the STC reacted very firmly to an Ethiopian demand for renewed aid. In a letter to the Swiss embassy in Ethiopia, he made it clear that the sTc had no interest whatsoever in repeating the experience of the hospital project, which he qualified as "a failure, at least partly."118

A similar conclusion can be drawn with regard to the nationalisation of Swiss assets in Ethiopia. In January 1976, the PMAC set up a commission to deal with compensations for nationalised assets and foreign ambassadors regularly reminded the government of its obligations. Yet, by the middle of 1978, its rules of procedure had still not been established. ${ }^{119}$ In the meantime, the Derg had strengthened its alliance with the USSR and had, thanks to major SovietCuban military intervention, defeated Somalia during the Ogaden War. As all attempts by the Carter administration to reach an agreement on compensation for US interests failed, the US government decided in October 1979 to close its Aid Mission in Ethiopia. By mid-1981, a single US firm had been compensated, probably in order that Ethiopia might again benefit from US bilateral and multilateral aid. Consequently, the Swiss authorities were pessimistic about their

to Dr. P. Nadelhaft and Dr. P. Riedl, doctors in the hospital, "Black Lion Hospital", 12.11.1976, SFA E2005A\#1991/16\#523*.

117 Letter from Fritz Bohnert, Swiss ambassador in Ethiopia, to the STC, "Spital in Addis Abeba. Ein Fehlobjekt unserer Hilfe? Und warum?” 21.11.1980, SFA E2025A\#1991/168\#657*.

118 Letter from Rolf Wilhelm to the Swiss embassy in Ethiopia, "Un appui suisse à l'Hôpitel du Lion Noir est à nouveau souhaité", 07.05.1981, SFA E2O25A\#1991/168\#657*.

119 Letter from Olivier Exchaquet to the DPA, "Nationalisierungen", 13.01.1976, SFA E2001E-o1\#1991/17_Bd. 758, B.34.66; letter from Hansjakob Kaufmann to the Trade Division, the Financial and Economic Service, and the DPIL, "Verstaatlichungen in Aethiopien", o7.o9.1976, ibid.; letter from Fritz Bohnert to the Trade Division and the DPA, "Gespräche des neuen amerikanischen Botschafters mit den äthiopischen Behörden", 21.08.1978, SFA E711O\#1989/32\#1361*. 
citizens' chances of obtaining any compensation for their losses, which were estimated at a total of $\mathrm{CHF} 22.5$ million by Bern. ${ }^{120}$

The example of the Duke of Harar Memorial Hospital underlined the limits of development cooperation as a political instrument. While the Swiss government's takeover of this project was explicitly requested by the Ethiopian Emperor and seems to have strengthened cordial relations with the old regime, it did not protect Switzerland from the criticism of the new rulers. It may even have accentuated bilateral tensions, as it drew the attention to the contrast between Bern's humanitarian engagement, and Swiss banks' welcome of misappropriated capital. From this viewpoint, the juxtaposition of CHF 140 million, the lowest amount mentioned for Ethiopian funds in foreign, mainly Swiss banks, and the CHF 8 million that the Swiss government and the University of Bern spent on the hospital, made it clear to Ethiopian observers which side benefited from bilateral relations.

The controversy surrounding the Ethiopian Emperor's Swiss bank accounts highlighted Switzerland's problematic role in North-South relations. Although there was a brief moment in late 1974 when a few members of the Swiss federal administration advocated relaxing Switzerland's banking secret and a parliamentary interpellation demanded the same, the issue never gained anywhere near as much sympathy in Switzerland as, for example, national liberation in Southern Africa. This is probably explained by the fact that the period of sustained pressure on the Swiss government and Swiss banks was very short. The debate flared up in mid-September 1974; in November, the Derg lost much of its international standing due to the widely publicized execution of opponents, and by the end of the year, the issue had died down. Thus, there was not much time for Swiss non-state actors to mobilise around this issue, especially as there was no pre-existing movement of solidarity with the Ethiopian population. Despite the autocratic character of the old regime and its shortcomings during the 1973-1974 famine, Haile Selassie was still widely regarded as a distinguished African statesman, which may have acted as a further deterrent to expressing solidarity with the new government.

By late 1976, the Swiss government's interest in the Horn of Africa was much diminished. Diplomatic relations with Somalia were unofficially suspended

120 Letter from Fritz Bohnert to the DPA, "Aethiopien: Kompensationsfrage. Regierungserklärung”, 08.10.1979, SFA E20o1E-o1\#1991/17_Bd. 759, B.34.66; letter from Edouard Brunner, DPA, to the Swiss embassy in Ethiopia, "Aethiopien: Entschädigung für verstaatlichte Vermögenswerte", 17.10.1979, ibid.; Serge François Salvi, DPA, memorandum, "Verstaatlichungen Aethiopien", o1.07.1981, ibid.; Arnold Hugentobler, DPA, memorandum, "Visite de l'Ambassadeur Bohnert, 6 août 1981”, 10.08.1981, SFA E20o1E-o1\#1991/17_Bd. 759, B.73.o. 
and, despite this country's formal alliance with the USSR, Bern mostly ignored it. Swiss-Ethiopian relations had normalised. In his final reports to Bern, Ambassador Olivier Exchaquet underlined that Haile Selassie's assets in Switzerland were no longer an issue in Ethiopia. While he had little hope of seeing commercial exchange increase in the foreseeable future because of the African country's poverty and its elites' focus on subsistence farming, the Derg's nationalisations rendered investment in Ethiopia unattractive. ${ }^{21}$ Although Exchaquet noted "Ethiopia's real slide to the Left", he was reassured that the country was still firmly anchored in the Western bloc from the point of view of military alliances, as it received most of its military supplies from the US.122 This would soon change. Only a year later, an unprecedented reversal of superpower alliances in the Horn of Africa would take place. Hoping to obtain US military support for its invasion of the Ogaden that caused the war of the same name between Somalia and Ethiopia, Siad Barre's regime broke with the USSR in November 1977 and Moscow subsequently began to officially support Ethiopia.

121 Final report from Olivier Exchaquet to the AD, 01.11.1976, pp. 2-6, SFA E2001E-o1\#1988/ $16 \# 3164$.

122 PR no 8 from Olivier Exchaquet, "L'Ethiopie à fin 1976 (Rapport final)", 12.11.1976, p. 5, SFA E2300-01\#1988/91\#3*. 